\title{
Conserving pattern and process in the Southern Ocean: designing a Marine Protected Area for the Prince Edward Islands
}

\author{
A.T. LOMBARD ${ }^{1 *}$, B. REYERS ${ }^{2}$, L.Y. SCHONEGEVEL ${ }^{2}$, J. COOPER ${ }^{3}$, L.B. SMITH-ADAO ${ }^{2}$, D.C. NEL ${ }^{4}$, \\ P.W. FRONEMAN ${ }^{5}$, I.J. ANSORGE ${ }^{6}$, M.N. BESTER 7 , C.A. TOSH ${ }^{7}$, T. STRAUSS $^{8}$, T. AKKERS $^{9}$, O. GON $^{10}$, \\ R.W. LESLIE ${ }^{9}$ and S.L. CHOWN ${ }^{11}$ \\ ${ }^{1}$ Marine Biology Research Centre, University of Cape Town, Rondebosch 7701, South Africa \\ ${ }^{2}$ Natural Resources and the Environment, CSIR, PO Box 320, Stellenbosch 7599, South Africa \\ ${ }^{3}$ Avian Demography Unit, Department of Statistical Sciences, University of Cape Town, Rondebosch 7701, South Africa \\ ${ }^{4}$ WWF-SA, Millennia Park, 16 Stellentia Avenue, Die Boord 7613, South Africa \\ ${ }^{5}$ Southern Ocean Group, Department of Zoology and Entomology, Rhodes University, PO Box 94, Grahamstown 6140, South Africa \\ ${ }^{6}$ Department of Oceanography, University of Cape Town, Rondebosch 7701, South Africa \\ ${ }^{7}$ Mammal Research Institute, Department of Zoology \& Entomology, School of Biological Sciences, University of Pretoria, Pretoria 0002, \\ South Africa \\ ${ }^{8}$ Department of Nature Conservation, Nelson Mandela Metropolitan University, Private Bag X6531, George 6530, South Africa \\ ${ }^{9}$ Marine and Coastal Management Branch, Department of Environmental affairs \& Tourism, Private Bag X2, Roggebaai 8012, South Africa \\ ${ }^{10}$ South African Institute for Aquatic Biodiversity, Private Bag 1015, Grahamstown 6140, South Africa \\ ${ }^{11}$ Centre for Invasion Biology, Department of Botany and Zoology, Stellenbosch University, Private Bag X1, Matieland 7602, South Africa \\ *gemsbok@mweb.co.za
}

\begin{abstract}
South Africa is currently proclaiming a Marine Protected Area (MPA) in the Exclusive Economic Zone (EEZ) of its sub-Antarctic Prince Edward Islands. The objectives of the MPA are to: 1) contribute to a national and global representative system of MPAs, 2) serve as a scientific reference point to inform future management, 3) contribute to the recovery of the Patagonian toothfish (Dissostichus eleginoides), and 4) reduce the bird bycatch of the toothfish fishery, particularly of albatrosses and petrels. This study employs systematic conservation planning methods to delineate a MPA within the EEZ that will conserve biodiversity patterns and processes within sensible management boundaries, while minimizing conflict with the legal toothfish fishery. After collating all available distributional data on species, benthic habitats and ecosystem processes, we used C-Plan software to delineate a MPA with three management zones: four IUCN Category Ia reserves (13\% of EEZ); two Conservation Zones (21\% of EEZ); and three Category IV reserves (remainder of EEZ). Compromises between conservation target achievement and the area required by the MPA are apparent in the final reserve design. The proposed MPA boundaries are expected to change over time as new data become available and as impacts of climate change become more evident.
\end{abstract}

Received 15 March 2006, accepted 20 August 2006

Key words: marine reserve design, pattern and process, sub-Antarctic, systematic conservation planning

\section{Introduction}

There is currently an increase in appreciation of the role that Marine Protected Areas (MPAs) can play in conserving marine biodiversity, while concurrently ensuring the sustainable use of living marine resources (e.g. Gell \& Roberts 2003, Gjerde \& Breide 2003). International endorsements for MPAs as a management tool include policy statements issued by the World Summit on Sustainable Development (United Nations 2002) and the World Parks Congress (IUCN 2004). These statements set a target for governments to protect $20-30 \%$ of all marine habitats under their jurisdiction (i.e. including Economic Exclusive Zone) by 2012. The South African Government has publicly committed itself to these goals (e.g. Department of Environmental Affairs and Tourism 2001/2002, 2004), and has recently announced its intention to declare its largest MPA yet, within the EEZ of the sub-
Antarctic Prince Edward Islands (Nel et al. 2005, South Africa 2005). The position of the islands (Marion and Prince Edward) in the southern Indian Ocean (Fig. 1) also places them within the area managed by the Commission for the Conservation of Antarctic Marine Living Resources (CCAMLR), whose Scientific Committee has recently endorsed the fact that a representative network of scientifically planned MPAs would be beneficial to furthering the guiding principles of both CCAMLR (Article 2) and the 1991 Madrid Protocol on Environmental Protection to the Antarctic Treaty (CCAMLRb 2005). It therefore follows that the development of an ecologically representative and scientifically planned MPA around the Prince Edward Islands is consistent with both national policy as well as the international treaties that apply in this area.

The Prince Edward Islands have been managed as a 


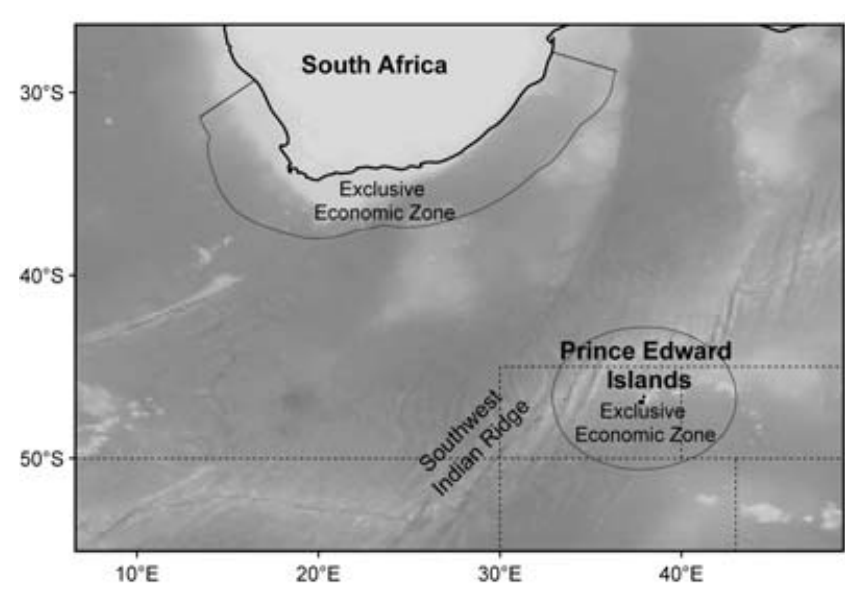

Fig. 1. The position of the Prince Edward Islands and the EEZ in the Southern Ocean, in relation to the CCAMLR statistical areas (dashed lines).

Special Nature Reserve since November 1995 (PEIMPWG 1996), but no marine component is included. To reduce the incidental mortality of procellariiform seabirds by longline fishing (Nel et al. 2002b, 2002c, 2003), however, no fishing activities have been permitted within the 12 nautical mile territorial waters since December 2004. Additionally, fishing activities by South African vessels in waters surrounding the islands in the main abide by the CCAMLR regulations and guidelines. The announcement of the South African Government in July 2004 of its intention to proclaim a major new MPA in the waters around the Prince Edward Islands (and not just the territorial waters) is proof of its national commitment to combat Illegal, Unreported and Unregulated (IUU) fishing in the Southern Ocean. This commitment is further supported by the purchase of new environmental patrol vessels, and ongoing bilateral negotiations aimed at enhancing international Monitoring, Control and Surveillance co-operation within the Southern Ocean.

A MPA around the Prince Edward Islands would fulfil four major objectives:

1. contribute to a national and global representative system of Marine Protected Areas, by providing protection for unique species, habitats and ecosystem processes (e.g. foraging grounds, shelf areas with increased nutrients, etc.),

2. serve as a scientific reference point that can inform the future management of the area,

3. contribute to the recovery of the Patagonian toothfish Dissostichus eleginoides, which has been so overexploited that its spawning biomass may be only a few percent of pre-exploitation levels just ten years ago (Brandão et al. 2002), and

4. aim to reduce the bycatch of the toothfish fishery, particularly of albatrosses and petrels (Nel \& Nel 1999,
Nel et al. 2002c) since the islands support $44 \%$ and $10 \%$ of the global populations of the wandering and grey-headed albatrosses, respectively (Crawford \& Cooper 2003).

More specific motivation for a large (inshore and offshore) MPA around the Prince Edward Islands includes the following:

- The uniqueness, pristine nature and high level of endemism of the islands themselves (Chown et al. 1998). In an assessment of the status of Southern Ocean islands, Chown et al. (2001) demonstrated that Prince Edward Island is one of the most pristine islands, emphasizing the need to limit future human intervention as far as possible. South Africa has recently nominated the islands and their territorial waters as a World Heritage Site (Fischer et al. 2006).

- Protection of the relationship between the marine and terrestrial environments, especially of the nutrient cycle driven by birds and seals (Froneman \& McQuaid in press, Smith \& Froneman in press). Protection of the terrestrial environment is thus reliant on a healthy marine environment.

- The foraging requirements of the top predators. Many bird and seal species breed on the islands (e.g. Hofmeyr \& Bester 1997, Pistorius et al. 1999, Crawford \& Cooper 2003), and forage either close to the islands (inshore feeders), or within and beyond the greater EEZ (offshore feeders). The birds especially are affected both indirectly (competition for resources), and directly (as bycatch), by fishing activities in the area. Many of these bird species are globally threatened (Crawford \& Cooper 2003).

- The islands are showing rapid change in step with global climate change (Pakhomov \& Chown 2003). Any anthropogenic reduction in the resilience of species that breed on the islands or forage within the EEZ may render these species locally extinct, for example, if sea surface temperatures change drastically (Mélice et al. 2003), or if the position of the oceanic fronts moves farther south (Lutjeharms et al. 2002). There is evidence that many birds and seals forage in the vicinity of these fronts (Jonker \& Bester 1998, Nel et al. 2001).

- The precautionary principle. Benthic surveys have been conducted only on the shelf between the two islands (Beckley \& Branch 1992, Branch et al. 1993), and very little is known about the benthic habitats within the EEZ. Undescribed species, as well as major geological features (such as hydrothermal vents on the Southwest Indian Ridge), are all likely to occur within the EEZ. Given that there is potential for oil and gas exploration in the area as well as an interest in tourism 
(especially if World Heritage Status is obtained), representative habitats need to be set aside to mitigate future threats.

- A number of shipping-related processes threaten the marine (and therefore terrestrial) environments. These include the introduction of alien species, via ballast water or on hulls (Frenot et al. 2005), pollution such as from oil spills (Cooper \& Condy 1988), and the discarding of fishery-related gear leading to harmful effects on both seals and birds (Nel \& Nel 1999, Hofmeyr et al. 2002). At present fishing vessels use the lee of the island to shelter from storms.

- A South African MPA within its sub-Antarctic EEZ will match and complement the two Marine Parks (equivalent to MPAs) recently declared by Australia in the EEZs of its sub-Antarctic island groups: Macquarie, and Heard and McDonald (Environment Australia 2001, 2005), thus contributing to a developing network of MPAs both within the Southern Ocean and globally. This network will also represent a west-east gradient in oceanographic biogeography and will lend support to ongoing efforts by international bodies such as the Antarctic Treaty through its Committee on Environmental Protection, CCAMLR and the World Conservation Union (IUCN) (e.g. Kelleher 1999, Gjerde \& Breide 2003, ATCM 2005, CCAMLR 2005a, 2005b).

Our aim has been to meet the four objectives listed previously by designing a MPA for the Prince Edward Islands EEZ that will: 1) conserve representative areas of biodiversity patterns (species and ecosystems) while simultaneously conserving biodiversity processes (e.g. foraging grounds, nutrient cycles), 2) avoid conflict with the fishing industry where possible, and 3) have sensible marine management boundaries. The study followed a systematic conservation planning approach (see Margules \& Pressey 2000) that collated all available information on biodiversity patterns and processes. Despite the previous extensive scientific research (Hänel \& Chown 1999, Chown \& Froneman in press), continuous spatial information that covers the entire EEZ is limited, and a number of different organizations and institutions maintain existing datasets. In addition to providing a central location within the appropriate Government agency for all existing data, our study also forms a spatial planning framework for future developments of MPA design.

\section{Methods}

\section{Study area}

The EEZ of the Prince Edward Islands covers $528020 \mathrm{~km}^{2}$ and lies in the Southern Ocean between approximately $42^{\circ} 45^{\prime}-50^{\circ} 45^{\prime} \mathrm{S}$, and $32^{\circ} 45^{\prime}-43^{\circ} \mathrm{E}$ (Fig. 1). It includes four

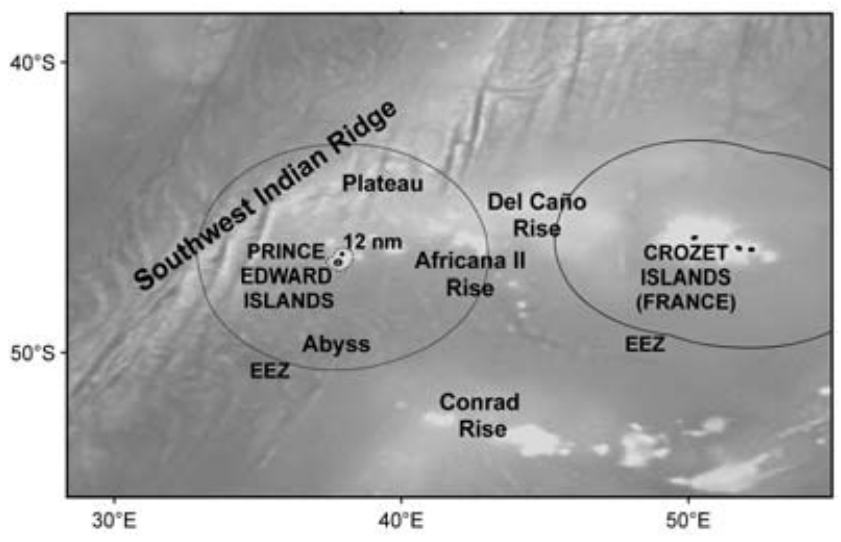

Fig. 2. Bathymetry of the Prince Edward Islands EEZ, with the Iles Crozet shown to the east. The four broad habitats within the EEZ include the Southwest Indian Ridge in the west, the plateau area in the northern half (mostly shallower than $3500 \mathrm{~m}$ ), the abyss in the southern half (deeper than $3500 \mathrm{~m}$ ), and the islands themselves. The territorial seas are shown at 12 nautical miles.

broad habitats: the Southwest Indian Ridge in the northwest; a plateau area with seamounts and rises in the northern half; an abyssal area in the southern half; and the islands and the shallow waters between them in the centre (Fig. 2). The two islands, Marion and Prince Edward, lying approximately at $46^{\circ} 45^{\prime} \mathrm{S}$ and $37^{\circ} 45^{\prime} \mathrm{E}$, have a combined terrestrial area of $339 \mathrm{~km}^{2}$. The Sub-Antarctic Front (SAF) lies to the north of the islands, and the Antarctic Polar Front (APF) lies to the south (Lutjeharms 1985). The southern SAF (SSAF) lies between the SAF and the APF. Consequently, three major water masses occur within the EEZ: sub-Antarctic surface waters (north of the SAF); northern polar frontal waters (between the SAF and the SSAF); and southern polar frontal waters (between the SSAF and the APF) (Ansorge \& Lutjeharms 2002).

The eastern border of the EEZ falls on the Africana II Rise, which itself forms part of the much larger Del Caño Rise, to the east of which lie France's Iles Crozet (Fig. 2). The Prince Edward and Crozet islands lie $1050 \mathrm{~km}$ apart, with c. $310 \mathrm{~km}$ separating their respective EEZs.

\section{Summary of the base data}

Our initial task was to collate and standardize all existing spatial datasets for the EEZ, as well as to generate new spatial data from existing data or from interviews with experts. Consultative workshops with stakeholders and an extensive literature survey completed the data-acquisition phase. All data are now housed within the implementation agency (Marine and Coastal Management Branch, Department of Environmental Affairs and Tourism), and are stored in Geographic Information Systems (GIS) format (ArcView 3.2 and ArcInfo 7, ESRI 1998). Those datasets that did not cover the entire EEZ were excluded from the systematic conservation planning process. Table I 
Table I. Datasets used in the systematic conservation planning of a marine protected area for the EEZ of the Prince Edward Islands in the Southern Ocean.

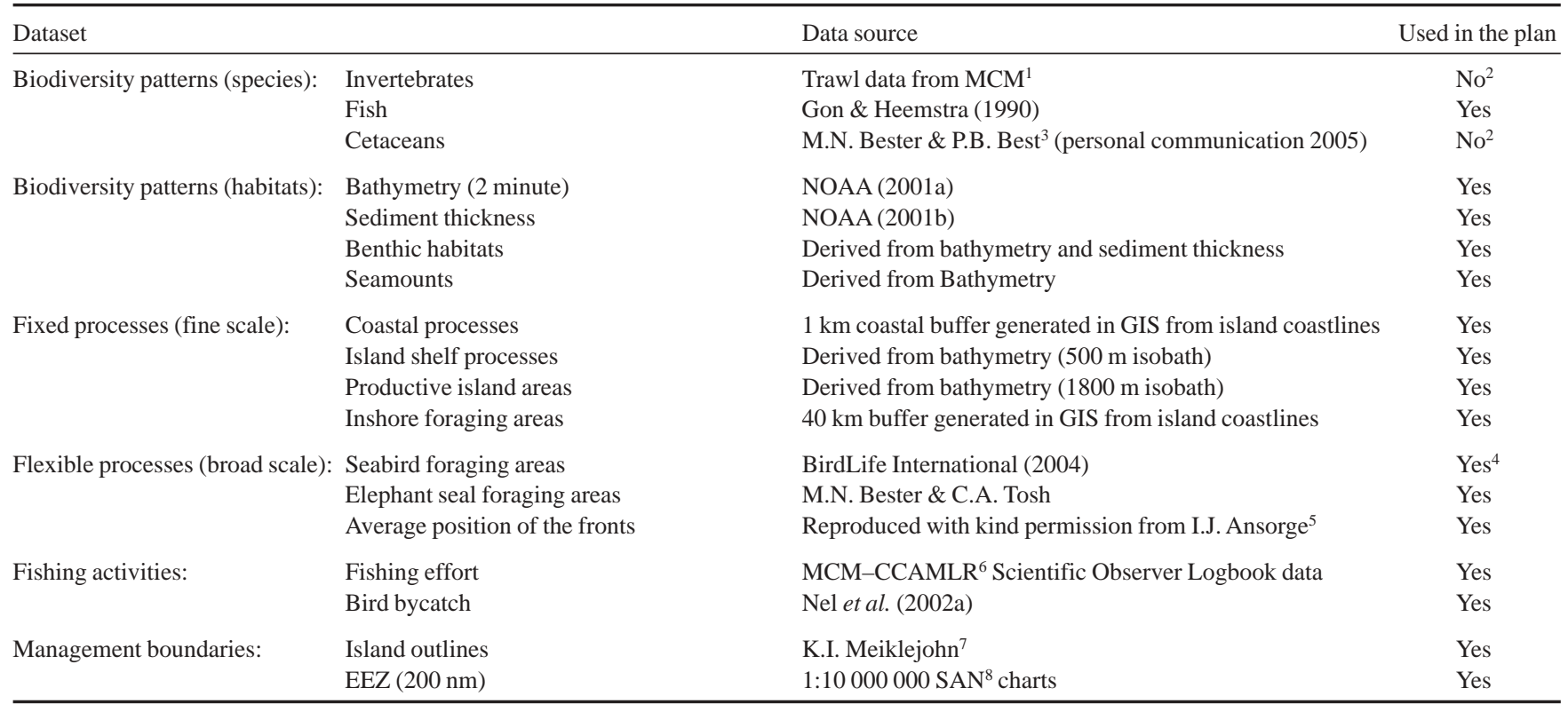

${ }^{1}$ Marine and Coastal Management (Department of Environment Affairs and Tourism), ${ }^{2}$ Data available for only limited parts of the EEZ (R.W. Leslie) ${ }^{3}$ Mammal Research Institute, University of Pretoria, ${ }^{4}$ Only data for birds tracked from the Prince Edward Islands were used (i.e. grey-headed and wandering albatrosses), ${ }^{5}$ Hydrographic data used for this study were collected during the MOES, MIOS and DEIMEC programmes funded through the South African National Antarctic Programme (Department of Environmental Affairs and Tourism), ${ }^{6}$ Commission for the Conservation of Antarctic Marine Living Resources ${ }^{7}$ Department of Geography, Geoinformatics \& Meteorology, University of Pretoria, ${ }^{8}$ South African Navy, Hydrographic Office

summarizes the data collated and developed for the study.

\section{Biodiversity patterns (species)}

A database of the fish occurring in the Prince Edward Islands EEZ was compiled using distribution and habitat data from Gon \& Heemstra (1990). A subset of 19 of these species was extracted for analyses. The subset contained all species from the family Nototheniidae (this is the largest sub-Antarctic family), as well as possible endemics, threatened species, and any species linked to benthic (as opposed to pelagic) habitats (Table II). Quantitative depthrange data from Gon \& Heemstra (1990) and two-minute bathymetry data were used to create two-minute GIS maps

Table II. The subset of 19 fish species used in the conservation planning analyses for the Prince Edward Islands.

\begin{tabular}{lll}
\hline Family & Species & Rationale for inclusion \\
\hline Halosauridae & Halosaurus macrochir Günther & Benthic \\
Synaphobranchidae & Diastobranchus capensis Barnard & Benthic \\
Muraenolepididae & Muraenolepis marmoratus Günther & Benthic \\
Muraenolepididae & Muraenolepis orangiensis Vaillant & Benthic \\
Moridae & Guttigadus kongi Markle \& Melendez & Benthopelagic \\
Macrouridae & Coryphaenoides filicauda Günther & Benthic \\
Macrouridae & Macrourus carinatus Günther & Benthic \\
Congiopodidae & Zanclorhynchus spinifer (Günther) & Benthic \\
Zoarcidae & Lycodapus antarcticus Tomo & Meso- to bathypelagic ${ }^{1}$ \\
Notothenidae & Dissostichus eleginoides Norman & Benthic to benthopelagic, heavily exploited \\
Nototheniidae & Gobionotothen marionensis Günther & Benthic, may be endemic to the islands \\
Nototheniidae & Lepidonothen larseni Lonnberg & Benthic, ecologically important ${ }^{2}$ \\
Nototheniidae & Lepidonotothen squamifrons Günther & Benthic, commercially exploited and may be threatened \\
Nototheniidae & Notothenia coriiceps Richardson & Benthic, ecologically important \\
Nototheniidae & Notothenia rossii Richardson & Benthic, rare \\
Nototheniidae & Paranotothenia magellanica Forster & Benthic, ecologically important \\
Harpagiferidae & Harpagifer georgianus Nybelin & Benthic, probably endemic to the Prince Edward Islands and South Georgia \\
Channichthyidae & Channichthys rhinoceratus Richardson & Benthic \\
Achiropsettidae & Mancopsetta milfordi Penrith & Benthic \\
\hline
\end{tabular}

${ }^{1}$ All specimens to date are from bottom trawls, but the species is associated with seamounts hence its inclusion

${ }^{2}$ Fulfils a key role in the food web 
of predicted habitat ranges for each species, within the EEZ. These GIS maps were overlaid to produce a final species richness layer. Only two-minute cells with more than four potential species were targeted in the conservation planning analyses. The maximum species richness of any one cell was 13.

\section{Biodiversity patterns (habitats)}

In addition to the four broad habitats within the EEZ (Fig. 2), a higher resolution map of benthic habitats was delineated. Owing to a lack of regional-scale data on bathymetry, the ETOPO (two-minute) global gridded data (NOAA 2001a) were used. Within this dataset, seafloor data for the EEZ were derived from satellite altimetry observations combined with quality-assured shipboard echo-sounding measurements (Smith \& Sandwell 1997).

To produce a map of unsampled benthic habitats for the entire EEZ, we combined bathymetry data with a map of sediment thickness (five-minute, NOAA 2001b), and produced a surrogate benthic habitat map for use in the conservation planning analyses. Bathymetry and sediment thickness were the only two biophysical variables for which complete coverage of the EEZ was available. Habitat classes in the final map were derived by dividing the bathymetry map into five biologically meaningful classes: 0 to $-200 \mathrm{~m}$ (island shelf), -200 to $-500 \mathrm{~m}$ (shelf of mounts and rises), -500 to $-1800 \mathrm{~m}$ (upper slope), -1800 to $-3500 \mathrm{~m}$ (lower slope) and < -3500 m (abyss) (Lombard et al. 2004). For consistency, the sediment map was similarly divided into five classes of thickness using a natural breaks (Jenks) classification method. Values ranged from 13 to $1021 \mathrm{~m}$. Spatial intersections of these two classified maps produced a final map of 21 different combinations of classes (four combinations did not exist). We treated these 21 combinations as benthic habitat surrogates, but recognize that no benthic data are currently available to test them for validity. The islands themselves were classified as one of the 21 habitats.

Owing to the increased biodiversity and productivity associated with seamounts and their vulnerability to fishery impacts (Rogers 1994, Roberts 2002), we produced a map of seamounts and rises, using the $800 \mathrm{~m}$ isobath as a cut off. Eleven seamounts and rises occur in the northern half of the EEZ.

\section{Biodiversity processes}

To delineate spatial surrogates for biodiversity processes, an understanding of the spatial and temporal variability of the major processes within the study area is required. These processes operate at a variety of scales, which should be recognized in MPA design.

Like other small oceanic islands, nutrient input to the Prince Edward Islands is primarily from the surrounding ocean (Smith 1978, 1987). Top predators (birds and seals), which use the islands to breed and moult, bring nutrients to the islands from two main sources: the islands' shelf area, and the pelagic environment (both within and outside the EEZ). Island run-off, driven by rainfall, then augments the nutrients in shelf waters. This close interaction between the marine and terrestrial environments is referred to as the islands' life support system (LSS), which has two components (Pakhomov \& Chown 2003).

Component one (the retention system) operates inshore and dominates when the SAF lies far to the north of the islands (Perissinotto \& Duncombe Rae 1990). Water is retained on the shallow island shelf, and increased macronutrient concentrations and water column stability generate phytoplankton blooms (the island mass effect, Allanson et al. 1985). Phytoplankton blooms then provide carbon to the benthos, which in turn provide food for the swimming shrimp, Nauticaris marionis Bate. This shrimp is an important component in the diet of a variety of inshoreforaging seabirds (Perissinotto \& McQuaid 1990, Pakhomov et al. 1999), and couples the pelagic environment to the islands' benthic environment (Perissinotto \& McQuaid 1990).

Component two operates offshore and dominates when the SAF is close to the islands. Two major food-supply mechanisms have been proposed for this component (Pakhomov \& Chown 2003). The first is a replenishing and pulsing mechanism that operates when flow-through regimes dominate between the islands (Perissinotto et al. 2000). Water is not trapped between the islands, and the Antarctic Circumpolar Current (ACC) advects zooplankton and nekton towards the islands, from west to east (Pakhomov \& Froneman 1999a). This food source is subsequently trapped by the shallow island shelf and is depleted by island predators during the daytime, but stocks are replenished at night by advection from upstream, when the predators are inactive (the replenishing hypothesis) (Perissinotto \& McQuaid 1992).

The second mechanism is associated with frontal movements and the formation of mesoscale eddies that are created as the ACC crosses the Southwest Indian Ridge (Ansorge \& Lutjeharms 2005). Elevated plankton and fish biomass are associated with the two major frontal systems (the SAF and the APF) in the vicinity of the islands (Pakhomov \& Froneman 2000). Although only the pelagic feeders from the islands (e.g. king penguins Aptenodytes patagonicus Miller and southern elephant seals Mirounga leonina L.) are able to travel to these fronts to forage (Bost et al. 1997, Jonker \& Bester 1998), the advection of these food sources to the islands can make them available to the more inshore foragers (Pakhomov \& Froneman 1999b). There is also evidence that mesoscale eddies created upstream of the islands are important feeding grounds for top predators (Hofmeyr \& Bester 1997, Klages \& Bester 1998, Pistorius et al. 1999, Nel et al. 2001). 
In order to capture these processes in a MPA design, we divided them into those that are fine scale and spatially fixed, and those that are broad scale and spatially flexible (variable).

\section{Fixed processes}

We defined a one-kilometre buffer around the islands as the coastal inshore zone (Coastal processes in Table I). This zone incorporates the dense stands of Macrocystis laevis Hay, an endemic kelp on the eastern coast of Marion Island approximately $100 \mathrm{~m}$ offshore in 5-20 m of water (Beckley \& Branch 1992). The kelp beds are areas of high biodiversity and add to ecosystem diversity on the shelf by providing important habitat for invertebrates (Pakhomov et al. 2002), and by trapping fresh water run-off from the islands, thereby reducing salinity and potentially promoting phytoplankton blooms (Pakhomov \& Froneman 1999b). This buffer also covers the foraging grounds of the Crozet cormorant Phalacrocorax [atriceps] melanogenis (Blyth), kelp gull Larus dominicanus Lichtenstein, the Kerguelen tern Sterna virgata Cabanis and Antarctic tern S. vittata Gmelin (Crawford \& Cooper 2003).

To capture the shelf-related processes of the inshore LSS, we chose the $500 \mathrm{~m}$ isobath around the islands (Island shelf processes in Table I). This incorporates the shelf areas of both islands as well as the area between them. The shelf supports a diverse and rich biomass of benthos (Gon \& Mostert 1992, Branch et al. 1993) and sustains a food web on which inshore-foraging seabirds rely. Concern has been raised because populations of inshore-foraging species (the Crozet cormorant, the gentoo penguin Pygoscelis papua Forster, and the rockhopper penguin Eudyptes chrysocome Forster) have decreased in recent years (Crawford et al. 1998, Crawford \& Cooper 2003).

Whereas these first two processes have benthic components, the third fixed process is of a pelagic nature and attempts to capture the "island mass effect" of increased Chl $a$ concentrations that are observed periodically in the downstream region of the islands. It was delineated with the $1800 \mathrm{~m}$ isobath around the islands (i.e. the upper/lower slope division). This area captures elevated Chl $a$ and myctophid fish concentrations around the islands, as well as a downstream area of high zooplankton biomass (Pakhomov \& Froneman 1999a, 2000, Ansorge \& Lutjeharms 2002) (Productive island areas in Table I). It may also be a nursery area for Patagonian toothfish (R.W. Leslie personal communcation 2005).

Although gentoo and rockhopper penguins are usually described as inshore feeders, their foraging ranges extend off the shelf to average distances of $29 \mathrm{~km}$ and $33 \mathrm{~km}$, respectively (Brown 1987, Wilson et al. 1989). To capture this and the phytoplankton blooms we buffered the islands by a distance of $40 \mathrm{~km}$ (Inshore foraging areas in Table I). This buffer also incorporates all territorial waters $(12 \mathrm{~nm}=$
$22.224 \mathrm{~km})$.

\section{Flexible processes}

A flexible process is an oceanographic or biological process that is not fixed in space, although its spatial occurrence may be predictable to varying degrees. Although flexible processes have formed part of terrestrial conservation plans in South Africa for some years (e.g. Cowling et al. 1999, 2003, Balmford 2003), their integration into MPA planning is still comparatively undeveloped. For the present study, we defined and mapped three flexible processes, namely foraging areas for wandering and grey-headed albatrosses (Diomedea exulans L. and Thalassarche chrysostoma, Forster, respectively); foraging areas for southern elephant seals; and the average positions of the SAF and the APF. These are all broad-scale, spatially variable processes that operate offshore, and the nutrient input contribution made by offshore foragers into the islands is by far the most significant (Pakhomov \& Froneman 1999b).

The Prince Edward Islands support $44 \%$ and $10 \%$ of the global populations of the wandering and grey-headed albatrosses, respectively. Both species are classified as Vulnerable, primarily as a result of population reductions since the 1980s (BirdLife International 2004), attributed mainly to mortality associated with longline fishing for tuna (Thunnus spp.) and Patagonian toothfish (Nel et al. 2002b, 2002c, 2003). During 1997-1998, breeding wandering and grey-headed albatrosses were tracked by satellite from Marion Island (Nel et al. 2000, 2001, 2002a). For the present study, habitat utilization was calculated using kernel density estimators from the Animal Movement formula developed by Hooge \& Eichenlaub (1997). Kernel density distribution maps were produced for each species using the same parameters used by the BirdLife International (2004) study. Maps show contours of 50\%, 51-75\%, and 76-95\% levels of habitat utilization. These contours represent the minimum polygon of densely clustered points that include a specified percent of the satellite points. Consequently, the $50 \%$ kernel represents the densest clustering of 50\% of the points recorded and highlights areas of maximum utilization.

To combine the habitat utilization maps from both bird species, we scored the 50\% habitat utilization polygons with a three, and the 51-75\%, and 76-95\% polygons with twos and ones, respectively. We overlaid the polygon maps, and summed the scores, thereby generating polygons with values ranging from six (maximum usage by both species) to one (used minimally by only one species).

Steady declines in numbers of southern elephant seals have been reported for the Prince Edward Islands for the last fifteen years (Pistorius et al. 1999, Bester \& Hofmeyr 2005, McMahon et al. 2005), although, the Marion Island population now seems to be stabilizing (Pistorius et al. 2004). Causes for these declines are not clearly understood 
(McMahon et al. 2005). For the present study, 48 satellite tracks for Marion Island southern elephant seals were analysed (Pangaea 2005). Outliers were removed, and habitat utilization maps were produced with the same methods used for the seabirds. Data from the seals were combined with the albatross data with the same scoring method generating polygons with values ranging from nine (maximum usage by all three species) to one (used minimally by only one species).

Given the important role played by the two oceanic fronts (the SAF and the APF) in maintaining the LSS of the Prince Edward Islands, we attempted to calculate their average positions within the EEZ, using sub-surface (200 m depth) temperature data (I.J. Ansorge unpublished data). Data from 771 points collected from cruises over eight years (between 1989 and 2005) were converted to raster grids and contoured. The position of the APF occurs at the $2^{\circ} \mathrm{C}$ contour, whereas the SAF can be split into a northern (SAF) and southern front (SSAF), lying at the $6{ }^{\circ} \mathrm{C}$ and $3.5^{\circ} \mathrm{C}$ contours, respectively (Froneman et al. 2002). These three fronts were extracted from the data for each of the eight years. Unfortunately the entire EEZ was not surveyed in all years, nor was there consistency in the area surveyed. Consequently, our maps of average frontal positions are incomplete and should be considered preliminary. Our contours, however, do fall within the described range of these frontal movements, which have a large spatial variation globally (Froneman et al. 2002, Lutjeharms et al. 2002).

\section{Fishing activities}

Demersal longline fishing for Patagonian toothfish is currently the main non-research-related human activity in the Prince Edward Islands' EEZ (low-impact tourism exists in the form of passing yachts). Sanctioned fishing in the EEZ began in October 1996, after considerable poaching by IUU vessels earlier in the year (Nel et al. 2002c). Since
1996, all legal South African fishing vessels operating in the EEZ have been required to carry CCAMLR Scientific Observers and their reports contain information on the fishing activities in the region from 1996 to the present day (2005). Data were extracted from these reports to map fishing localities. We chose a single point (the line setting start point) to represent the location of each longline set by each vessel. The spatial distribution of fishing effort and catch data are summarized in Lombard (2006).

\section{Study area outlines}

Coastlines for Marion and Prince Edward Island were provided by K.I. Meiklejohn (University of Pretoria) and were derived from 2000 Landsat imagery. Territorial and jurisdictional zones (for example, the EEZ) were digitised from the South African Navy Maritimes Zones chart SAN MZ 1 (1:10 000 000, Hydrographic Office, S.A. Navy, published in 1995).

\section{Systematic conservation planning}

During the past two decades, the field of systematic conservation planning (Margules \& Pressey 2000), has developed rapidly. Systematic planning is based on the need to conserve a representative sample of a region's biodiversity and to ensure its persistence through the exclusion of threatening processes and the inclusion of ecological and evolutionary processes that maintain and generate biodiversity (Cowling et al. 2003).

A systematic conservation plan relies on the definition of conservation targets (quantitative expressions of a region's conservation goals), which define how much of each biodiversity pattern (e.g. habitat types or species), and which biodiversity processes (e.g. foraging areas), should be included within the protected area boundaries. Once biodiversity patterns and processes have been spatially delineated, the study area is subdivided into planning units

Table III. Targets for the systematic conservation planning of a marine protected area for the EEZ of the Prince Edward Islands.

\begin{tabular}{lll}
\hline Biodiversity patterns and processes & Target \\
\hline Biodiversity patterns (species): & Fish & All 2 minute cells with four to 13 species $^{1}$ \\
Biodiversity patterns (habitats): & Broad-scale habitats & MPA to represent each of the four broad-scale habitats \\
& Major water masses & MPA to represent each of the three major water masses \\
& Benthic habitats & $20 \%$ of the area of each of 20 habitats, and all of the Land habitat \\
& Seamounts & All of the 11 seamounts and rises \\
Fixed processes: & Coastal processes & Entire area of 1 km coastal buffer \\
& Island shelf processes & Entire area of inshore island shelf \\
& Inshore foraging areas & Entire area of productive island areas \\
& Sea bird and elephant seal foraging areas & Entire area of 40 km buffer \\
& MPA to incorporate major movement axes as shown by the combined bird and \\
& Average position of the fronts & seal habitat utilization data, as well as all values from eight to nine (see Fig. 6c) \\
& MPA to incorporate average positions of the SAF, SSAF and APF (see Fig. 6c).
\end{tabular}

\footnotetext{
${ }^{1}$ Areas with one to three species covered too much of the EEZ to serve as practical targets
} 


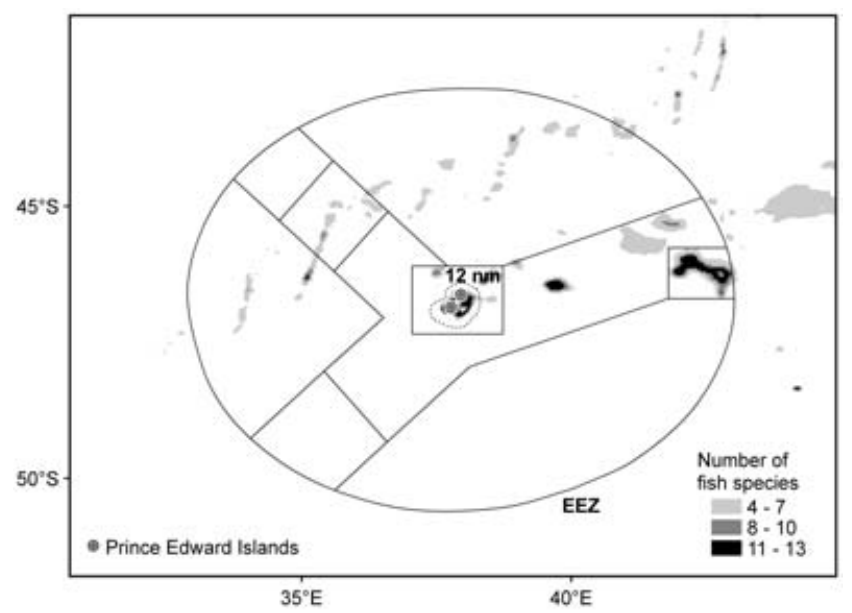

Fig. 3. Species richness of a subset of 19 fish species in the Prince Edward Islands EEZ (see Table II). Only two-minute grid cells with $\geq$ four species are shown, overlaid on the proposed MPA boundaries (see Fig. 7).

(typically grid squares or hexagons). The contribution of each planning unit to the quantitative targets is then calculated, and an efficient and practical spatial arrangement of planning units is then identified to meet all the targets. Various software systems are available to perform these calculations, for example C-Plan and MARXAN (Pressey 1999, Ball \& Possingham 2000, Possingham et al. 2000).

Targets defined for the present study are listed in Table III. The EEZ was divided into 9839 grid cells or planning units of $4 \times 4$ nautical miles, and the contribution of each of these units to the targets was calculated with CPlan software (Pressey 1999). C-Plan calculates the irreplaceability value of each planning unit - where irreplaceability is a value (from $0-1$ ) of the likelihood that the planning unit will be needed to meet targets (Pressey 1999, Ferrier et al. 2000).

\section{Design rules}

To maximize effective implementation of a planning design, protected area planning should always be conducted within an implementation framework (Pierce et al. 2005, Knight et al. 2006). We identified three primary factors that would facilitate implementation of our recommended MPA boundaries: the final area of the MPA, the overlap of the MPA with current legal fishing activities, and the complexity of the boundaries. Consequently, we constrained our planning design by the following four rules:

1. Minimize the area required to meet targets,

2. Avoid current legal fishing activities where choices exist, but do not compromise biodiversity targets,

3. Keep the boundaries of the MPA as straight lines, joining points that are on exact degrees and minutes, and

4. Exclude all planning units that are only partially within the EEZ (i.e. on the boundary, $n=438$ ).

\section{Analyses}

Our MPA design proceeded in three steps using C-Plan.

In Step 1 we identified four zones as equivalent to Strict Nature Reserves (IUCN Category Ia). Each of these was representative of one of the four broad-scale habitats, and

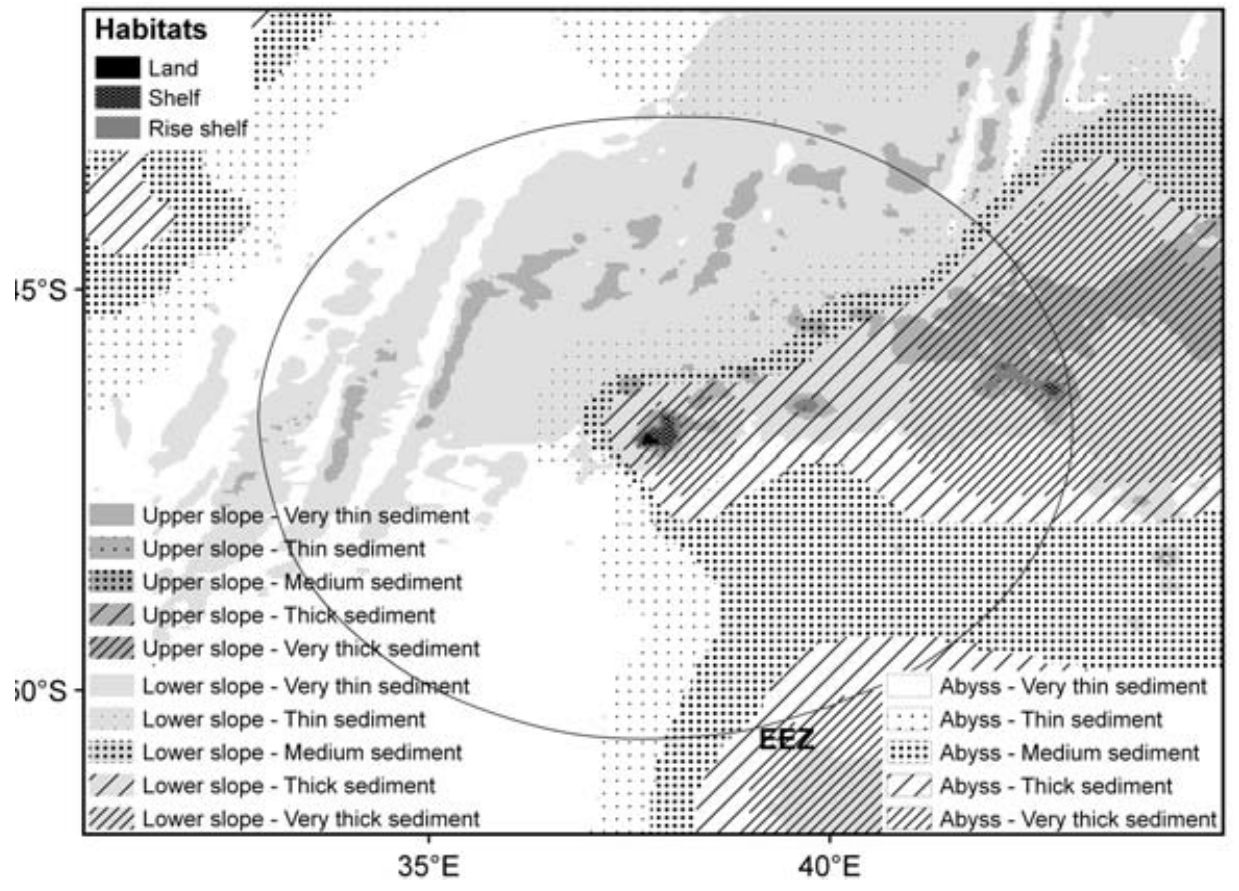

Fig. 4. Benthic habitats defined for the EEZ, using combinations of bathymetry and sediment thickness classes. The habitats labelled Shelf and Rise shelf are actually combinations of two Shelf habitats and three Rise shelf habitats, respectively, but these have been combined into single shades for this figure, owing to their very small areas within the EEZ. 
Table IV. Biodiversity patterns and processes represented within the four IUCN Category Ia reserves proposed for the Prince Edward Islands MPA (see Fig. 7).

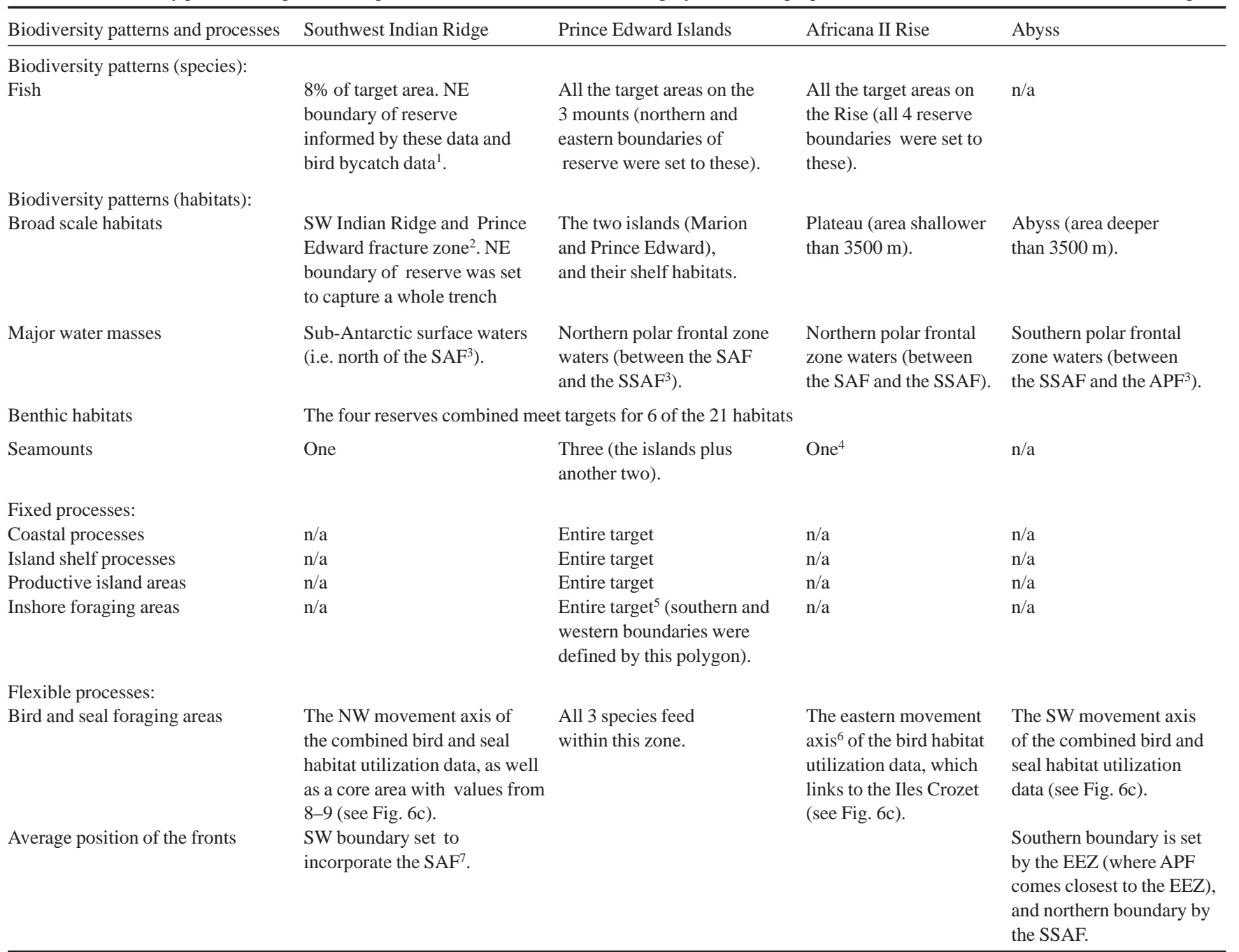

\footnotetext{
${ }^{1}$ CCAMLR Scientific Observer reports, ${ }^{2}$ Area likely to contain active volcanoes and hydrothermal vents (I. McLachlan, Petroleum Agency South Africa, personal communication 2005). Sperm whales may utilize the deep canyons (M. Meyer, personal communication 2005). ${ }^{3}$ SAF (sub-Antarctic Front), SSAF (southern sub-Antarctic Front), APF (Antarctic polar Front). ${ }^{4}$ This area may be a replenishment zone for many fish species (R.W. Leslie, personal communication 2005). ${ }^{5}$ This zone also incorporates all territorial waters. Also many whale species (M. Meyer, personal communication 2005). All bird bycatch data for the area also included in boundaries. ${ }^{6}$ This axis is also used by many seabirds from the Crozets (BirdLife International 2004). ${ }^{7}$ The average
}

the three water bodies, and was also delineated to achieve as many of the targets in the targets table as possible. Boundary lines were straight, and connected points on exact degrees and minutes (i.e. no seconds). Areas of more recent legal fishing activity were avoided where possible (i.e. where choices existed between planning units that contributed equally to targets). Table IV describes each reserve, and the rationale behind its boundaries. One of these four reserves (around the islands) met all four fixed process targets (Table III).

In Step 2, we connected the four reserves from Step 1 with straight lines, to incorporate the three movement axes defined by the highest values of the bird and elephant seal habitat utilization data. Again, we attempted to avoid areas of more recent fishing activity where choices existed. Because the Category Ia reserves were placed in areas that also maximized targets for frontal zone average positions (Table IV), the axes also incorporated the areas of variability of the frontal positions. Areas within these axes were defined as Conservation Zones and were not given an IUCN category because their exact management status is still under consideration. Together with the Category Ia reserves, the Conservation Zones met all the flexible process targets.

At this point, the only targets that were not met by Steps 1 and 2 were those for fish, benthic habitats, and seamounts (Table III). In Step 3, we assigned all planning units that had $>90 \%$ of their areas within the proposed Step 1 and 2 reserves to the "reserved" status within C-Plan. We then calculated the contribution of all remaining planning units to meeting outstanding targets. The planning units identified by Step 3, along with the proposed Category Ia reserves and 


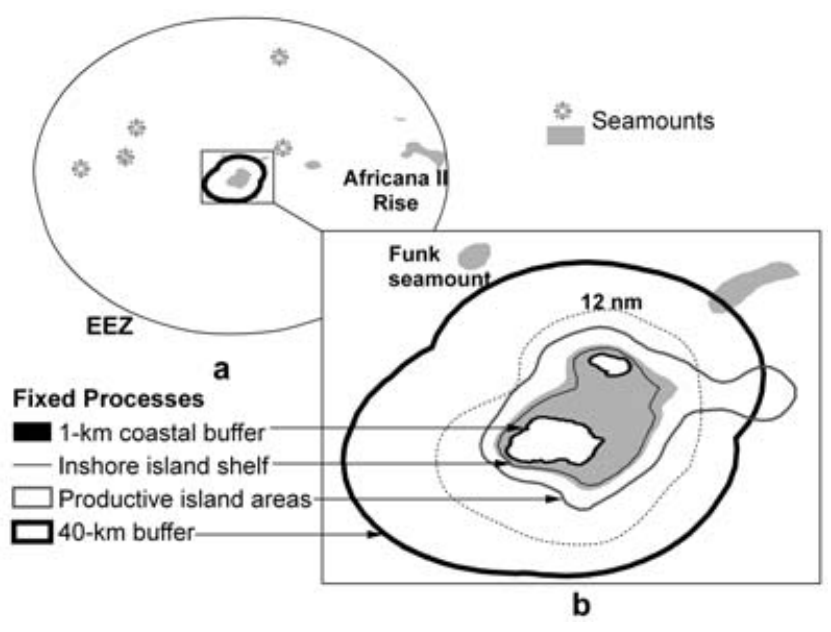

Fig. 5. a. The 11 seamounts (and rises) defined within the EEZ. The scale of the figure precludes the shading of the five smaller seamounts, which are shown as symbols $(*)$. b. corresponds to the boundaries of the proposed Prince Edward Island Category Ia reserve (see Fig. 7), and also shows the four fixed processes.

Conservation Zones, met all the benthic habitat targets. However, Step 3 violated design rules one to three, and still did not meet all fish species richness and seamount targets.

\section{Results}

\section{Biodiversity patterns (species)}

Species richness of the 19 fish species, calculated per twominute cell, is shown in Fig. 3. Areas with $\geq$ four species are restricted to the shallower, northern half of the EEZ, and areas of highest richness are concentrated on the shelves of the islands, seamounts, and the tops of the Southwest Indian Ridge.

\section{Biodiversity patterns (habitats)}

The 21 habitat surrogates defined for the EEZ are shown in Fig. 4. Only two habitats make up just under half of the EEZ: abyss with very thin sediments in the south west (24\% of EEZ), and lower slopes with very thin sediments in the northern half (25\%). The Southwest Indian Ridge dominates the western areas, and shallower habitats (islands, island shelf, seamounts, rises and their shelves) are limited to the northern half of the EEZ, particularly on a west-east axis that joins the islands to Africana II Rise. Nine of 21 habitats contribute $<1 \%$ to the EEZ's total area (these are all upper slope and shallower habitats).

Figure 5 shows the distribution of the 11 seamounts and rises defined for this study. Many are well known fishing grounds for the Patagonian toothfish (R.W. Leslie personal communication 2005).
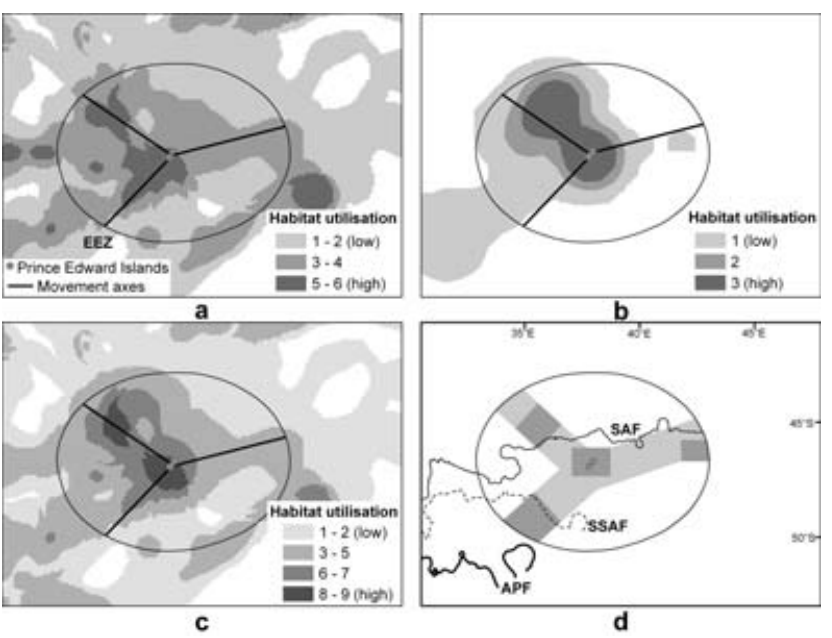

Fig. 6. Habitat utilization maps for a. tracked wandering and greyheaded albatrosses, and b. southern elephant seals. Combined habitat utilization map are sown in c. for both albatross species and elephant seals. Foraging movement axes are plotted in each map. d. shows the average position of the major oceanic fronts (SAF, SSAF and APF), overlaid on the proposed MPA boundaries (see Fig. 7).

\section{Fixed processes}

The four fixed processes are illustrated in Fig. 5b. All are associated with the islands themselves, and the $40 \mathrm{~km}$ buffer incorporates the other three processes, except for a small portion of the productive island areas process in the east.

\section{Flexible processes}

Habitat utilization maps for albatrosses and seals, tracked from Marion Island, show foraging patterns concentrated

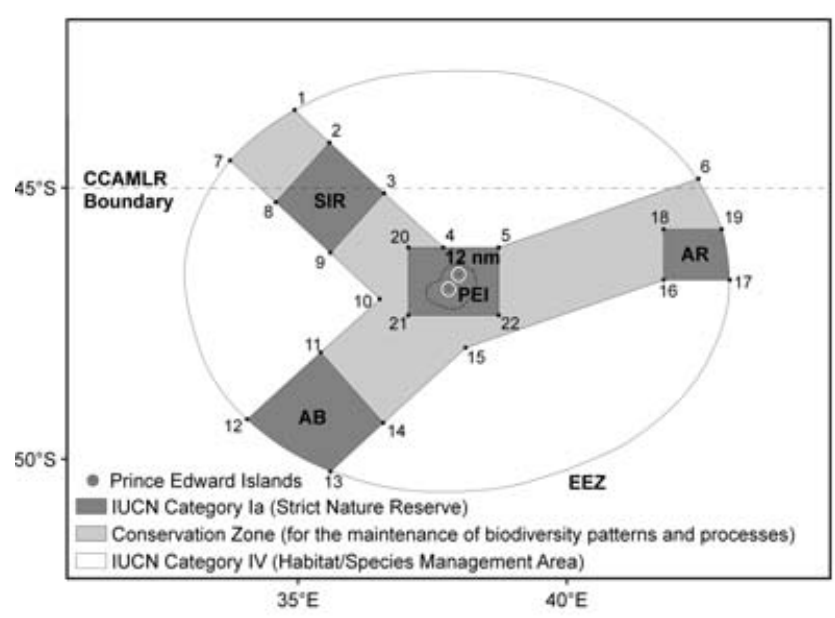

Fig. 7. The proposed boundaries for the Prince Edward Islands MPA. The four Category Ia reserves are: Southwest Indian Ridge (SIR), Prince Edward Islands (PEI), Africana II Rise (AR), and Abyss (AB) (see also Table IV). The CCAMLR Convention Area lies to the south of the CCAMLR boundary. 
Table V. Areas and EEZ percentages of the reserve categories proposed for the Prince Edward Islands Marine Protected Area (see Fig. 7).

\begin{tabular}{lrrrr}
\hline Reserve category & $\begin{array}{c}\text { Area } \\
\left(\mathrm{km}^{2}\right)\end{array}$ & $\begin{array}{c}\text { \% } \\
\text { EEZ }\end{array}$ & $\begin{array}{c}\text { Sum area } \\
\left(\mathrm{km}^{2}\right)\end{array}$ & $\begin{array}{c}\% \\
\text { EEZ }\end{array}$ \\
\hline IUCN Category Ia - Ridge & 17926 & 3 & & \\
IUCN Category Ia - Islands & 17903 & 3 & & \\
IUCN Category Ia - Africana II Rise & 9438 & 2 & & \\
IUCN Category Ia - Abyss & 23157 & 4 & 68425 & 13 \\
Conservation Zones (axes) & 112208 & 21 & 112208 & 21 \\
IUCN Category IV (remainder of EEZ) & 347386 & 66 & 347386 & 66 \\
Total & 528019 & 100 & 528019 & 100 \\
\hline
\end{tabular}

along three main axes (Fig. 6). The bird and seal axes are in similar positions, radiating out from the islands in a northwest direction across the plateau area to the Southwest Indian Ridge, and in a south-west direction, again towards the ridge. Birds also use a third axis from the islands to the Africana II Rise, which forms part of the larger Del Caño Rise, which leads to the Iles Crozet farther east (Fig. 2). Although we were aware of spatial data for bird species tracked from the Iles Crozets that forage within the South African EEZ, these data were not included in our analyses but are mentioned later in the discussion.

Average positions of the fronts, as calculated by our study, are shown in Fig. 6d. The three foraging axes take birds and seals across these fronts, and therefore across their zones of variability (Lutjeharms \& Valentine 1984). Although not shown in the figure, the APF regularly moves into the southern sector of the EEZ (Lutjeharms 1985).

\section{Systematic conservation planning}

The four Category Ia reserves defined in Step 1 are illustrated in Fig. 7 and described fully in Table IV. Their combined areas constitute 13\% of the EEZ (Table V), and they meet all broad habitat and major water mass targets, as well as all fixed process targets. They also contribute substantially to all other targets (Table VI). No extractive activities may occur within IUCN Category Ia reserves, but although the northern three proposed Category Ia reserves do fall on fishing grounds specifically targeted during 1996-2005, most of the more recent fishing activity (2002-2005) is dispersed across the plateau region, and is

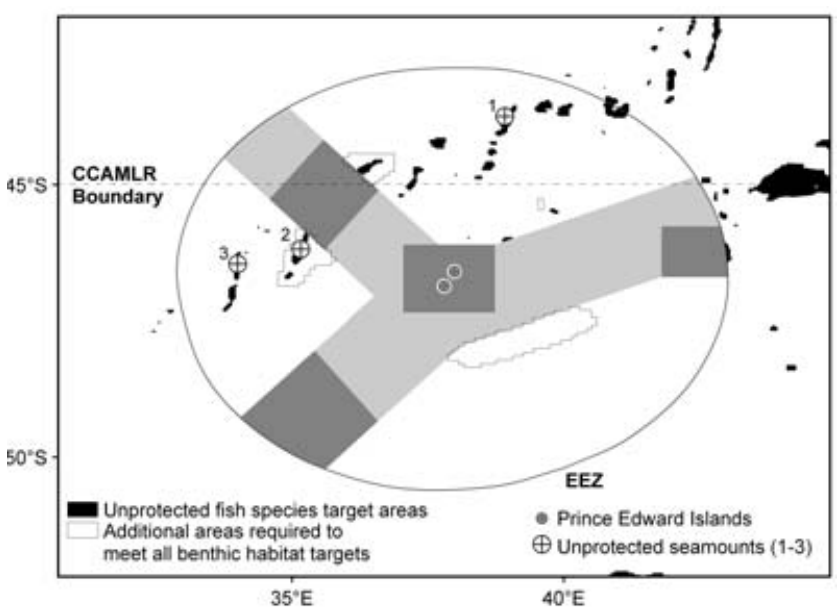

Fig. 8. The relationship between the proposed Category Ia reserves (dark grey) and the Conservation Zones (light grey), and the three biodiversity patterns (fish target areas, seamounts and benthic habitats) whose targets are not met within these reserves.

not concentrated in the proposed Category Ia reserves. The proposed Category Ia reserve in the south (Abyss) was not fished. Total fishing effort and catch data per planning unit are described in detail in Lombard (2006).

The three axes defined in Step 2 to meet flexible process targets constitute an additional 21\% of the EEZ (Table V), and we have defined them provisionally as Conservation Zones, owing to the fishing grounds and shallower habitats present within them that require management and possible protection. These Conservation Zones also contribute substantially to outstanding targets (Table VI). Design rules were not compromised in Steps 1 and 2, and unmet targets at this point included $30 \%$ of the species rich fish areas, five benthic habitats, and three seamounts (Table VI).

To meet all benthic habitat targets, we used the C-Plan software in Step 3 to identify the smallest number of planning units, that were spatially clustered around the Category Ia reserves and Conservation Zones, that would meet outstanding benthic habitat targets, while simultaneously attempting to meet fish and seamount targets. Figure 8 shows that four additional areas are required: one small area of three planning units in the north east (for Upper slope-Thin sediment habitats); two other

Table VI. Summary of the conservation planning steps and targets met by each step (data in each row include data of previous row).

\begin{tabular}{|c|c|c|c|c|c|c|c|}
\hline \multirow[b]{2}{*}{ Step } & \multirow[b]{2}{*}{ Description } & \multirow[b]{2}{*}{$\begin{array}{l}\text { No. of PUs }{ }^{1} \\
\text { required }\end{array}$} & \multirow[b]{2}{*}{ Fish } & \multicolumn{4}{|c|}{ Targets met } \\
\hline & & & & $\begin{array}{l}\text { Benthic habitats } \\
\qquad(n=21)\end{array}$ & $\begin{array}{l}\text { Seamounts } \\
\qquad(n=11)\end{array}$ & Fixed processes & Flexible process \\
\hline 1 & Four Category Ia reserves & 1135 & $46 \%^{2}$ & $6^{3}$ & $5^{4}$ & All & Partially \\
\hline 2 & Conservation Zones & 3077 & $70 \%$ & 16 & 8 & All & All \\
\hline 3 & Additional areas for benthic habitat targets & 3508 & $77 \%$ & All & 9 & All & All \\
\hline
\end{tabular}

${ }^{1}$ Planning units, total number completely within EEZ = 9401

${ }^{3}$ Six of the 21 benthic habitats

\footnotetext{
${ }^{2} 46 \%$ of 2-minute grid cells with $\geq$ four species

${ }^{4}$ Five of the 11 seamounts
} 
areas on the Southwest Indian Ridge (for Upper slope-Very thin sediment, and Lower slope-Very thin sediment habitats); and a larger area in the south-east to meet outstanding targets for Abyss-Medium sediments. However, these additional areas violate two of the design rules (they incorporate more recent fishing grounds and are not bordered by straight lines), while not substantially contributing to outstanding fish and seamount targets (Table VI). In order to meet all targets fully, the MPA would require all four areas of Step 3, as well as another axis running along most of the ridge and plateau within the EEZ (Fig. 8).

We thus recommend that the results of Steps 1 and 2 (Fig. 7) are used as provisional MPA boundaries, and that the remaining areas within the EEZ are classified as IUCN Category IV reserves (Habitat/Species Management Areas) in accordance with the CCAMLR proposal that the whole CCAMLR area be so classified (76\% of the Prince Edward Islands' EEZ falls within the CCAMLR area). Biodiversity patterns with targets not met by the Category Ia reserves and Conservation Zones will therefore be able to benefit from a management strategy within these Category IV areas. The coordinates that define the reserve boundaries are provided in Lombard et al. (2005).

\section{Discussion}

Marine protected area design has received much attention in recent times, primarily because of the collapse of many fisheries globally (Pauly et al. 2002), and the negative ecosystem effects of fishing activities (Worm et al. 2005). Globally, we are now at the end of a 50-year period of intense fishing, and there is a transition between target stock management, to ecosystem management (Gell \& Roberts 2003). The roles of MPAs as reference points, stock replenishment zones, management tools, scientific reserves, for the protection of threatened species and habitats, and as representative areas of marine habitats, are receiving increased attention and support (e.g. Kelleher 1999, Russ 2002, Gjerde \& Breide 2003, Blundell 2004). Although the management of Southern Ocean resources is relatively well developed within CCAMLR, the protection of representative and threatened habitats, and habitats reserved for scientific study because of their pristine nature, is still in its infancy. We hope that this study will provide a starting point for further systematic studies in the region.

We stress that the fisheries benefits of MPAs are separate from the role of MPAs in biodiversity protection. Although we have addressed mainly the biodiversity benefits in this study, we emphasize that the MPA will be necessary for the recovery of depleted stocks of exploited Patagonian toothfish and will increase the yield of this collapsed fishery. The MPA is thus beneficial for biodiversity, as well as current fishery stakeholders.

Although the provisional MPA boundaries in Fig. 7 meet most of the targets defined for the study, the design rules force us to accept a compromise. This compromise means that the following targets fall outside of the Category Ia reserves and the Conservation Zones: $23 \%$ of the areas potentially rich in fish; remaining targets for five of the 21 benthic habitats; and three of the 11 seamounts. Meeting these targets will require the expansion of the Category Ia reserves and the Conservation Zones to include almost the entire northern half of the EEZ.

In this study, we have tackled the unknown effects of climate change by developing spatial surrogates for ecosystem processes, and by placing reserve boundaries to capture these processes. The boundaries also traverse latitudinal and longitudinal gradients, thereby maximizing the chances of incorporating the shifting position of the oceanic fronts. These fronts are critical to the offshore component of the Prince Edward Islands' life-support system, and operate over very broad scales. There is evidence that the average position of the SAF is shifting farther south, and that this movement is favouring the flowthrough system that supports the offshore foragers, over the retention system that supports the inshore foragers (Pakhomov \& Chown 2003). Ongoing monitoring of the bird and seal populations on the islands and their movement patterns, as well as of the positions of oceanic fronts, is required if we wish to modify the MPA boundaries in the future to cater for climate change.

We have suggested that the MPA boundaries proposed here may need to be changed in the future to accommodate shifting processes, and these changes may also be driven by new data becoming available. There are some obvious gaps in the data upon which this preliminary planning was based. For example, no data exist on the exact foraging grounds of fur seals, king penguins, and other bird species breeding on the Prince Edward Islands. However, foraging areas of seabirds tracked from the nearby Crozet Islands (sooty Phoebetria fusca Hilsenberg and wandering albatrosses and white-chinned petrels Procellaria aequinoctialis L., BirdLife International 2004), overlap largely with those from the Prince Edward Islands. Of note is the importance of the axis between the two islands, along the Del Caño Rise (Fig. 2). Many birds use this movement axis, and this emphasizes the importance of co-management of Southern Ocean resources by neighbouring countries, and the areas of the High Seas in between their EEZs.

Benthic habitat data are another obvious gap, and we attempted to overcome this problem by using bathymetry and sediment thickness data as habitat surrogates. Only quantitative surveys in the EEZ will enable us to test these surrogates, but at least our stratification of the EEZ can serve as a starting point for planning future surveys.

It is important to note that although a systematically planned MPA within the Prince Edward Islands will greatly enhance the conservation and management of this area, this measure should not operate in isolation. To be effective, the 
MPA needs to be nested within an effective broader (and non-spatial) management framework for the Islands EEZ and the broader region. Marine ecosystems of the Prince Edward Islands are partially reliant on ecosystem processes that occur outside the EEZ, either within the Crozet Islands EEZ or on the High Seas (but within the CCAMLR area of jurisdiction). The foraging axis on the Del Caño Rise has already been mentioned. There is also a fracture zone in the Southwest Indian Ridge, to the South West of the islands and adjacent to the EEZ. This zone is an area of reliably high productivity, as a result of meso-scale eddies that are generated as the ACC crosses the ridge. These eddies are targeted by top predators breeding on the islands (Hofmeyr \& Bester 1997, Klages \& Bester 1998, Pistorius et al. 1999, Nel et al. 2001). It is therefore important that the South African MPA system around the Prince Edward Islands is nested within a regional spatial conservation plan for the CCAMLR region. It is comforting to know that moves are already afoot to develop just such a plan (CCAMLR 2005b). It is intended that the Prince Edward Islands MPA will be zoned for management purposes. The exact nature and regulatory regime of each zone remain under discussion, but recommendations for the three categories of reserves proposed in this study are provided in Lombard et al. (2005).

\section{Recommendations}

We conclude by summarizing our recommendations for the Prince Edward Islands MPA. Management and policy recommendations are provided in Lombard et al. (2005), and the spatial overlap of the proposed MPA with the legal fishery is presented in Lombard (2006). We recommend that:

1. The establishment of four IUCN Category Ia reserves (Fig. 7) to meet biodiversity targets, and for the recovery of the Patagonian toothfish fishery.

2. These four Category Ia reserves be connected via the Conservation Zones indicated in Fig. 7, in order to meet process targets (foraging grounds of top predators and oceanic frontal zones), and the long-term recovery of the toothfish fishery.

3. The rest of the EEZ be managed as an IUCN Category IV reserve, in accordance with CCAMLR proposals.

4. In order to detect climate changes that may impact the boundaries of the proposed MPA, sea surface temperatures and shifts in the position of the major frontal systems to the north and south of the islands be monitored.

5. In order to detect biotic responses to climate change, pelagic phyto- and zooplankton, and fish communities, and foraging patterns of birds and seals be monitored.

\section{Acknowledgements}

This project would not have been possible without the initial proposal made by the Prince Edward Islands Management Committee and funding and logistical support of Sanlam, WWF South Africa, the Marine and Coastal Management Branch and Antarctica and Islands Directorate of the Department of Environmental Affairs \& Tourism (South Africa), and the Charl van der Merwe Trust. The project relied on a broad participatory process involving a range of experts whose time and contributions are gratefully acknowledged. We thank C.G. Attwood, R. Ball, L.E. Beckley, G.M. Branch, R.J.M. Crawford, H. Currie, S. Davies, L. Drapeau, T. Fairweather, B. Flanagan, N. Kock, C.D. McQuaid, M. Meyer, P. Mullins, A. Omardien, S.L. Petersen, P.G. Ryan, F.E. Taylor and B.P. Watkins. Their input was invaluable. We also thank two anonymous reviewers for their constructive suggestions to improve this manuscript.

\section{References}

Allanson, B.R., Boden, B., Parker, L. \& Duncombe Rae, C. 1985. A contribution to the oceanology of the Prince Edward Islands. In Siegfried, W.R., Condy, P.R. \& Laws, R.M., eds. Antarctic nutrient cycles and food webs. Berlin: Springer, 38-45.

Ansorge, I.J. \& LutJeHARMS, J.R.E. 2002. The hydrography and dynamics of the ocean environment of the Prince Edward Islands. Journal of Marine Systems, 37, 107-127.

Ansorge, I.J. \& LutJeharms, J.R.E. 2005. Direct observations of eddy turbulence at a ridge in the Southern Ocean. Geophysical Research Letters, 32, doi:10.1029/2005GL022588.

ATCM (Antarctic Treaty Consultative Meeting). 2005. Final Report of the Twenty-Eighth Antarctic Treaty Consultative Meeting. Stockholm, Sweden, 6-17 June 2005. http://www.ats.aq.

Ball, I.R. \&. Possingham, H.P. 2000. MARXAN (V1.8.2): Marine Reserve Design Using Spatially Explicit Annealing, a Manual.

BALMFORD, A. 2003. Conservation planning in the real world: South Africa shows the way. Trends in Ecology and Evolution, 18, 435-438.

BeCKLEy, L. \& BRANCH, G.M. 1992. A quantitative SCUBA-diving survey of the sublittoral macrobenthos at sub-Antarctic Marion Island. Polar Biology, 11, 553-563.

Bester, M.N. \& Hofmeyr, G.J.G. 2005. Numbers of elephant seals at Prince Edward Island, Southern Ocean. South African Journal of Wildlife Research, 35, 85-88.

BIRDLIFE INTERNATIONAL. 2004. Tracking ocean wanderers: the global distribution of albatrosses and petrels. Results from the Global Procellariiform Tracking Workshop, 1-5 September, 2003, Gordon's Bay, South Africa. Cambridge, UK: BirdLife International.

Blundell, T. 2004. Turning the tide. Addressing the impact of fisheries of the marine environment. summary of the Royal Commission on Environmental Pollution's report. London: The Royal Commission on Environmental Pollution, 377 pp.

Bost, C.A., Georges, J.Y., Guinet, C., Cherel, Y., Pytz, K., Charrassin, J.B., Handrich, Y., Zorn, T., LAGE, J. \& LE MAHO, Y. 1997. Foraging habitat and food intake of satellite-tracked king penguins during the austral summer at Crozet Archipelago. Marine Ecology Progress Series, 150, 21-33.

Branch, G.M., Attwood, C.G., Gianakouras, D. \& Branch, M.L. 1993. Patterns in the benthic communities on the shelf of the sub-Antarctic Prince Edward Islands. Polar Biology, 13, 23-34. 
Brandão, A., Watkins, B.P., Butterworth, D.S. \& MilleR, D.G.M. 2002. A first attempt at an assessment of the Patagonian toothfish (Dissostichus eleginoides) resource in the Prince Edward Islands EEZ. CCAMLR Science, 9, 11-32.

BRown, C.R. 1987. Traveling speed and foraging range of macaroni and rockhopper penguins at Marion Island. Journal of Field Ornithology, 58, 118-125.

CCAMLR. 2005a. Marine Protected Areas in the Context of CCAMLR. A Management Tool for the Southern Ocean. CCAMLR Marine Protected Areas (MPA) Workshop, Silver Spring, Maryland, USA. 29 August-1 September 2005. WS-MPA-05/4.

CCAMLR. 2005b. Report of the 24th meeting of the Commission. Hobart, Australia: CCAMLR. www.ccamlr.org

Chown. S.L. \& Froneman, P.W. eds. In press. The Prince Edward Archipelago. Land-sea interactions in a changing ecosystem. Stellenbosch: Sun Media.

Chown, S.L., Gremmen, N.J.M. \& Gaston, K.J. 1998b. Ecological biogeography of southern ocean islands: species-area relationships, human impacts, and conservation. The American Naturalist, 152, 562-575.

Chown, S.L., Rodrigues, S.L., Gremmen, N.J.M. \& Gaston, K.J. 2001. World Heritage status and conservation of southern ocean islands. Conservation Biology, 15, 550-557.

COOPER, J. \& Condy, P.R. 1988. Environmental conservation at the subAntarctic Prince Edward Islands: a review and recommendations. Environmental Conservation, 25, 317-326.

Cowling, R.M., Pressey, R.L., Lombard, A.T., Desmet, P.G. \& Ellis, A.G. 1999. From representation to persistence: requirements for a sustainable system of conservation areas in the species-rich mediterranean-climate desert of southern Africa. Diversity and Distributions, 5, 51-71.

Cowling, R.M., Pressey, R.L., Rouget, M. \& Lombard, A.T. 2003. A conservation plan for a global biodiversity hotspot - the Cape Floristic Region, South Africa. Biological Conservation, 112, 191-216.

CraWford, R.J.M. \& CoOper, J. 2003. Conserving surface-nesting seabirds at the Prince Edward Islands: the roles of research, monitoring and legislation. African Journal of Marine Science, 25, 415-426.

Crawford, R.J.M., Hurford, J., Greyling, M. \& Nel, D.C. 1998. Population size and trends of some seabirds at Marion Island. New Zealand Natural Sciences Supplement, 23, 42.

Department of EnVironmental AfFairs And Tourism. 2001/2002. A Bioregional Approach to South Africa's Protected Areas. Pretoria: Department of Environmental Affairs \& Tourism.

DePARTMENT OF ENVIRONMENTAL AfFAirs AND Tourism. 2004. Extract from remarks by Marthinus van Schalkwyk. Minister of Environmental Affairs and Tourism, speaking at Kalk Bay Harbour on 4 June 2004. Pretoria: Department of Environmental Affairs \& Tourism. www.environment.gov.za

EnVironment Australia. 2001. Macquarie Island Marine Park Management Plan. Canberra: Department of the Environment and Heritage.

EnVironment Australia. 2005. Heard Island and McDonald Islands Marine Reserve Management Plan. Canberra: Department of the Environment and Heritage.

ESRI 1998. Arc and Grid Command References. Redlands, CA: Environmental Systems Research Institute.

Ferrier, S., Pressey, R.L. \& Barrett, T.W. 2000. A new predictor of the irreplaceability of areas for achieving a conservation goal, its application to real-world planning, and a research agenda for further refinement. Biological Conservation, 93, 303-325.

Fischer, D., Heydenrich, R., Cooper, J. \& Bester, M.N. 2006. Prince Edward Islands: World Heritage Nomination. Pretoria: Department of Environmental Affairs \& Tourism.

Frenot, Y., Chown, S.L., Whinam, J., Selkirk, P.M., Convey, P., Skotnicki, M. \& Bergstrom, D.M. 2005. Biological invasions in the Antarctic: extent, impacts and implications. Biological Review, 80, $45-72$.
Froneman, P.W. \& McQuaid, C.D. In press. Biology of the oceanographic environment. In Chown. S.L. \& Froneman, P.W., eds. The Prince Edward Archipelago. Land-sea interactions in a changing ecosystem. Stellenbosch: Sun Media.

Froneman, P.W., Ansorge, I.J., Vumazonke, L. Gulekana, K., Bernard, K., WebB, A.M., Leukes, W., Risien, C.M., Thomalla, S., Hermes, J., Knott, M., Anderson, D., Hargey, N., Jennings, M., Veitch, J., LutJeharms, J.R.E. \& McQuaid, C.D. 2002. Physical and biological variability in the Antarctic Polar Frontal Zone: report on the research cruise 104 of the M.V. S.A. Agulhas. South African Journal of Science, 98, 534-536.

Gell, F.R. \& Roberts, C.M. 2003a. Benefits beyond boundaries: the fishery effects of Marine reserves. Trends in Ecology and Evolution, 18, 9, 448-455.

Guerde, K. \& Breide, C. eds. 2003. Towards a strategy for High Seas Marine Protected Areas. Proceedings of the IUCN, WCPA and WWF Experts Workshop on High Seas Marine Protected Areas 15-17 January 2003, Malaga, Spain. World Conservation Union: Gland.

Gon, O. \& HeEmstra, P.C. eds. 1990. Fishes of the Southern Ocean. Grahamstown: J.L.B. Smith Institute of Ichthyology, 462 pp.

Gon, O. \& Mostert, D. 1992. Aspects of the ecology of two nototheniid fish species in the inshore zone of the sub-Antarctic Marion Island. South African Journal of Antarctic Research, 22, 59-67.

Hänel, C. \& CHOwn, S.L. 1998. An Introductory Guide to the Marion and Prince Edward Island Special Nature Reserves. Pretoria: Department of Environmental Affairs and Tourism, $80 \mathrm{pp}$.

HÄNEL, C. \& CHOwN, S.L. 1999. Fifty years at Marion and Prince Edward Islands: a bibliography of scientific and popular literature. South African Journal of Science, 95, 87-112.

Hofmeyr, G.J.G. \& Bester, M.N. 1997. Changes in population sizes and distribution of fur seals at Marion Island. Polar Biology, 17, 150-58.

Hofmeyr, G., De Maine, M., Bester, M., Kirkman, S., Pistorius, P. \& MAKHADO, A. 2002. Entanglement of pinnipeds at Marion Island, Southern Ocean: 1991-2001. Australian Mammology, 24, 141-146.

Hooge, P.N. \& Eichenlaub, B. 1997. Animal movement extension to Arcview. Version 1.1. Alaska Anchorage, AK: Biological Science Center, U.S. Geological Survey.

IUCN. 2004. Recommendations from the 4th World Parks Congress. www.iucn.org/themes/wcpa/wpc2003/

Jonker, F.C. \& Bester, M.N. 1998. Seasonal movements and foraging areas of adult southern female elephant seals, Mirounga leonina, from Marion Island. Antarctic Science, 10, 21-30.

Klages, N.T.W. \& Bester, M.N. 1998. Fish prey of fur seals Arctocephalus spp. at subantarctic Marion Island. Marine Biology, 131, 559-566.

Knight, A.T., Driver, A., Cowling, R.M., Maze, K., Desmet, P.G., Lombard, A.T., Rouget, M., Botha, M.A., Boshoff, A.F., Castley, J.G., Goodman, P.S., Mackinnon, K., Pierce, S.M., Sims-Castley, R., SteWART, W.I. \& VON HASE, A. 2006. Designing systematic conservation assessments that promote effective implementation: best practice from South Africa. Conservation Biology, 20, 739-750.

Lombard, A.T. 2006. Developing the Prince Edward Islands Marine Protected Area (MPA). Updated maps and statistics of the legal Patagonian toothfish (Dissostichus eleginoides) fishery in South Africa's Exclusive Economic Zone around the Prince Edward Islands. Stellenbosch: WWF Sanlam Marine Programme, South Africa.

Lombard, A.T., Reyers, B., Schonegevel, L., Cooper, J., Smith-Adao, L., Nel, D., Froneman, W., Ansorge, I., Bester, M., Tosh, C., Strauss, T., Akkers, T., Gon, O., Leslie R. \& Chown, S. 2005. Developing the Prince Edward Islands Marine Protected Area (MPA). CSIR Report Number: CSIR/NRE/ECO/ER/2005/0013/C, South Africa.

Lombard, A.T., Strauss, T., Harris, J., SinK, K., Attwood, C. \& Hutchings, L. 2004. South African National Spatial Biodiversity Assessment 2004: Technical Report. Volume 4: Marine Component. Pretoria: South African National Biodiversity Institute, 26-37. 
LUTJEHARMS, J.R.E. 1985. Location of frontal systems between Africa and Antarctica: some preliminary results. Deep-Sea Research, 32, 1499-1509.

LutJeharms, J.R.E. \& Valentine, H.R. 1984. Southern Ocean thermal fronts south of Africa. Deep-Sea Research, 31, 1461-1476.

LutJeHARMS, J.R.E., JAMALOODIEN, S. \& ANSORGE, I.J. 2002. The temporal displacement of ocean fronts south-east of Africa. South African Journal of Science, 98, 304-306.

Margules, C.R. \& Pressey, R.L. 2000. Systematic conservation planning. Nature, 405, 243-253

McMahon, C.R., Hindell, M.A., Burton, H.R. \& Bester, M.N. 2005. Comparison of southern elephant seal populations, and observations of a population on a demographic knife-edge. Marine Ecology Progress Series, 288, 273-283.

Mélice, J.-L., LutJeharms, J.R.E., Rouault, M. \& Ansorge, I.J. 2003. Sea-surface temperatures at the sub-Antarctic islands Marion and Gough during the past 50 years. South African Journal of Science, 99, 363-366.

NeL, D.C. \& NeL, J.L. 1999. Marine debris and fishing gear associated with seabirds at sub-Antarctic Marion Island, 1996/97 and 1997/98: in relation to longline fishing activity. CCAMLR Science, 6, 85-96.

Nel, D.C., Lombard, A.T., Akkers, T., Cooper, J. \& Reyers, B. 2005. Progress towards the declaration of a large Marine Protected Area around South Africa's sub-Antarctic Prince Edward Islands. CCAMLR Marine Protected Areas (MPA) Workshop, Silver Spring, Maryland, USA. 29 August-1 September 2005. WS-MPA-05/15.

Nel, D.C., Lutjeharms, J.R.E., PaKhomov, E.A., Ansorge, I.J., Ryan, P.G. \& KLAGES, N.T.W. 2001. Exploitation of mesoscale oceanographic features by grey-headed albatrosses Thalassarche chryosostoma in the southern Indian Ocean. Marine Ecology Progress Series, 217, 15-26.

Nel, D.C., Nel, J.C., Ryan, P.G., Klages, N.T.W., Wilson, R.W. \& RoBERTSON, G. 2000. Foraging ecology of grey-headed mollymawks at Marion Island, southern Indian Ocean, in relation to longline fishing activity. Biological Conservation, 96, 219-231.

Nel, D.C., Ryan, P.G., CraWford, R.J.M., CoOper, J. \& Huyser, O.A.W. 2002a. Population trends of albatrosses and petrels at sub-Antarctic Marion Island. Polar Biology, 25, 81-89.

Nel, D.C., Ryan, P.G., NEL, J.L., Klages, T.W., Wilson, R.P., ROBERTSON, G. \& TucK, G.N., 2002b. Foraging interaction between wandering albatrosses Diomedea exulans breeding on Marion Island and long-line fisheries in the southern Indian Ocean. Ibis, 144 (on-line), E141-E154.

NeL, D.C., Ryan, P.G. \& WatKInS, B.P. 2002c. Seabird mortality in the Patagonian toothfish longline fishery around the Prince Edward Islands, 1996-2000. Antarctic Science, 14, 151-161.

Nel, D.C., Taylor, F., Ryan, P.G. \& CoOper, J. 2003. Population dynamics of the wandering albatross Diomedea exulans at Marion Island: longline fishing and environmental influences. African Journal of Marine Science, 25, 503-517.

NOAA. 2001a. 2-minute Gridded Global Relief Data (ETOPO2). National Geophysical Data Center.

NOAA. 2001b. Sediment thickness of the world's ocean and marginal seas. National Geophysical Data Center.

Paкhomov, E.A. \& Chown, S.L. 2003. The Prince Edward Islands: Southern Ocean oasis. Ocean Yearbook, 17, 348-379.

Pakhomov, E.A. \& Froneman, P.W. 1999a. Macroplankton/micronekton dynamics in the vicinity of the Prince Edward Islands (Southern Ocean). Marine Biology, 134, 501-515.

Pakhomov, E.A. \& Froneman, P.W. 1999b. The Prince Edward Islands pelagic ecosystem, south Indian Ocean: a review of achievements, 1976-1990. Journal of Marine Systems, 18, 355-367.

Pakhomov, E.A. \& Froneman, P.W. 2000. Composition and spatial variability of macroplankton and micronekton within the Antarctic Polar Frontal Zone of the Indian Ocean during austral autumn 1997. Polar Biology, 23, 410-419.
Pakhomov, E.A. \& Froneman, P.W., Kuun, P.J. \& Balarin, M. 1999. Feeding dynamics and respiration of the bottom-dwelling caridean shrimp Nauticaris marionis Bate, 1888 (Crustacea: Decapoda) in the vicinity of Marion Island (Southern Ocean). Polar Biology, 21, 112-121.

PaKhomov, E.A., Kaehler, S. \& McQuaid, C.D. 2002. Zooplankton community structure in the kelp beds of the sub-Antarctic Prince Edward Archipelago: are they a refuge for larval stages? Polar Biology, 25, 778-788.

PANGAEA (Publishing Network For Geoscientific And Environmental Data) 2005. Marine mammal tracking database. Bremerhaven: Alfred Wegener Institute.

Pauly, D., Christensen, V., Guenette S., Pitcher, T.J., Sumaila, U.R., Walters, C.J., Watson, R. \& ZeLLeR, D. 2002. Towards sustainability in world fisheries. Nature, 418, 689-695.

PEIMPWG (Prince Edward Islands Management Plan Working Group) 1996. Prince Edward Islands Management Plan. Pretoria: Department of Environmental Affairs \& Tourism.

Perissinotto, R. \& Duncombe RaE, C.M. 1990. Occurrence of anticyclonic eddies on the Prince Edward Plateau (Southern Ocean): effects on phytoplankton biomass and production. Deep-Sea Research, 37, 777-793.

PerissinotTo, R. \& McQuaid, C. 1990. Role of the sub-antarctic shrimp Nauticaris marionis in coupling benthic and pelagic food-webs. Marine Ecology Progress Series, 64, 81-87.

PerissinotTo, R. \& McQuaid, C.D. 1992. Deep occurrence of the giant kelp Macrocystis laevis in the Southern Ocean. Marine Ecology Progress Series, 81, 89-95.

Perissinotto, R., Lutjeharms, J.R.E. \& van Ballegooyen, R.C. 2000. Biological-physical interactions and pelagic productivity at the Prince Edward Islands, Southern Ocean. Journal of Marine Systems, 24, 327-341.

Pierce, S.M., Cowling, R.M., Knight, A.T., Lombard, A.T., Rouget, M. \& Wolf, T. 2005. Systematic conservation planning products for landuse planning: interpretation for implementation. Biological Conservation, 125, 441-458.

Pistorius, P.A., Bester, M.N. \& Kirkman, S.P. 1999. Dynamic agedistributions in a declining population of southern elephant seals. Antarctic Science, 11, 445-450.

Pistorius, P.A., Bester, M.N., Lewis, M.N., Taylor, F.E., Campagna, C. \& KIRKMAN, S.P. 2004. Adult female survival, population trend, and the implications of early primiparity in a capital breeder, the southern elephant seal (Mirounga leonina). Journal of Zoology, 263, 107-119.

Possingham, H.P., Ball, I.R. \& Andelman, S. 2000. Mathematical methods for identifying representative reserve networks. In FERSON, S. \& Burgman, M., eds. Quantitative methods for conservation biology. New York: Springer, 291-305.

Pressey, R.L. 1999. Applications of irreplaceability analysis to planning and management problems. Parks, 9, 42-51.

RoBERTS, C.M. 2002. Deep impact: the rising toll of fishing in the deep sea. Trends in Ecology and Evolution 242, 242-245.

Rogers, A.D. 1994. The biology of seamounts. Advances in Marine Biology, 30, $305-350$.

RUSs, G.R. 2002. Yet another review of marine reserves as reef fishery management tools. In SALE, P.F., ed. Coral reef fishes: dynamics and diversity in a complex ecosysatem. San Diego, CA: Academic Press, 421-443.

SMith, V.R. 1987. The environment and biota of Marion Island. South African Journal of Science, 83, 211-220.

Smith, V.R. \& Froneman, P.W. In press. Nutrient cycles and land-sea interactions. In Chown. S.L. \& Froneman, P.W., eds. The Prince Edward Archipelago. Land-sea interactions in a changing ecosystem. Stellenbosch: Sun Media.

Smith, W.H.F. \& SANDwELL, D.T. 1997. Global sea floor topography from satellite altimetry and ship depth soundings. Science, 277, 1956-1962. 
South Africa. 2005. Towards the creation of a Marine Protected Area around South Africa's sub-Antarctic Prince Edward Islands. XXVIII Antarctic Treaty Consultative Meeting, Stockholm 2005. Information Paper IP 19, 5 pp.

United Nations. 2002. Report of the World Summit on Sustainable Development. www.johannesburgsummit.org/
Wilson, R.P., Nagy, K.A. \& OBST, B.S. 1989. Foraging ranges in penguins. Polar Record, 25, 303-307.

Worm, B., SAndow, M., Oschlies, A., Lotze, H.K. \& Myers, R.A. 2005. Global patterns of predator diversity in the open oceans. Science, 309, 1365-1369. 